\title{
Pembuatan Paper Kit Test Ekstrak Etanol Bunga Telang (Clitoria ternatea L.) Untuk Identifikasi Formalin Pada Makanan
}

\author{
Ni Made Detia Suryadnyani a, ${ }^{* *}$, Agus Dwi Ananto b, 2, Rizqa Fersiyana Deccati c, 3 \\ aProgram Studi Farmasi, Fakultas Kedokteran, Universitas Mataram, J1. Majapahit No.62, Dasan Agung Baru, Mataram, 83I26 \\ 1'detiasurya@gmail.com*; ${ }^{2}$ agus_da@unram.ac.id; ${ }^{3}$ rizqa.fd@unram.ac.id \\ *korespondensi penulis
}

INFO ARTIKEL

Diterima :

05-07-202I

Direvisi :

II-07-202I

Disetujui :

12-07-2021

\section{Kata kunci:}

Formalin;

Ekstrak bunga telang;

Paper kit test.

\section{ABSTRAK}

Temuan makanan berformalin di Indonesia khususnya provinsi NTB masih dijumpai. Analisa makanan berformalin membutuhkan biaya yang mahal sehingga tidak terjangkau untuk semua kalangan. Ekstrak etanol bunga telang (Clitoria ternatea L.) berpotensi sebagai indikator formalin pada makanan. Penelitian ini bertujuan untuk membuat paper kit test ekstrak etanol bunga telang untuk identifikasi formalin pada makanan. Teknik pembuatan paper kit test adalah dengan immobilisasi reagen dengan cara merendam paper kit test ke suatu reagen. Ekstrak etanol bunga telang dan dalam bentuk paper kit test dilakukan uji pada dua kelompok kontrol yaitu kontrol positif (sampel makanan berformalin) dan kelompok negatif (sampel makanan tanpa formalin). Hasil pengujian paper kit test dibandingkan dengan test kit formalin pasaran untuk melihat perbedaan hasil uji. Interpetasi hasil dilihat berdasarkan perubahan warna pada ekstrak maupun paper kit test. Hasil positif ditunjukkan dengan perubahan warna dari biru gelap menjadi biru cerah. Pada penelitian ini diperoleh kesimpulan yaitu ekstrak etanol bunga telang mampu mendeteksi kandungan formalin pada makanan, sedangkan dalam bentuk paper kit test belum mampu mendeteksi karena belum berhasil dibuat. Paper kit test belum dapat dibuat karena tidak terabsorbsinya antosianin pada Whattman.

Key word:
Formalin;
ethanol extract of butterfly pea;
paper kit test.

\section{ABSTRACT}

Formalin's foods in Indonesia, especially in the province of NTB are still found. Analysis of formalin's food is expensive so it's not affordable for all people. Ethanol extract of butterfly pea (Clitoria ternatea L.) has potential as an indicator of formalin in food. The purpose of this research is to make paper kit test of butterfly pea ethanol extract to detect formalin in food. The technique of making a paper kit test is reagent immobilization by immersing paper into reagent. Extract and paper kit test were tested on two control groups, positive (food contains formalin) and the negative (food without formalin). The results of the paper kit test was compared with the formalin test kit on the market to see the difference in test results. The interpretation of the results was seen based on the color changes on instruments. A positive result is indicate by a color change from dark blue to bright blue. In this study, it can be concluded that the ethanol extract is able to detect the formalin in food, while the paper kit test hasn't been able because it hasn't been successfully made. Paper kit test hasn't been successfully made because anthocyanin couldn't absorbs in Whattman.

This is an open access article under the CC-BY-SA license. 


\section{Pendahuluan}

Penggunaan formalin pada bahan makanan masih dapat ditemui. Pada tahun 2017, temuan BPOM menunjukkan sebanyak 192 sampel makanan positif mengandung formalin di Indonesia (Badan Pengawas Obat dan Makanan, 2017). Kandungan formalin di makanan pada provinsi NTB ditemukan sebanyak 7 sampel positif dari 163 sampel yang diuji (Badan Pengawas Obat dan Makanan, 2018).

Formalin adalah senyawa formaldehid dalam air dengan konsentrasi $37 \%$ yang mempunyai efek antibakteri (Siswandono, 2016). Pada zaman Mesir kuno hingga sekarang formalin sering digunakan sebagai bahan pengawet mayat (Rohmatun, 2010). Formalin tidak boleh dikonsumsi maupun digunakan dalam bahan makanan karena dapat menyebabkan alergi, sakit perut, muntah serta menyebabkan lesi gastrointestinal (Mamun dkk., 20I4). International Agency for Research on Cancer mengklasifikasikan formalin ke dalam kelompok I. Kelompok I adalah yaitu kelompok yang bersifat karsinogenik pada manusia (International Agency for Research on Cancer, 2006).

Kandungan formalin pada makanan dapat dianalisis menggunakan instrumen Kromatografi Gas Spektrofotometri Massa (KG-MS) serta Kromatografi Cair Kinerja Tinggi (KCKT). Kedua instrument tersebut memiliki kelebihan dari segi batas deteksi tetapi memiliki kekurangan dari segi biaya dan kepraktisan. Analisa formalin juga dapat dilakukan dengan uji reaksi warna (pereaksi Nash. asam kromatopat dan paper kit test). Diantara uji reaksi warna tersebut, paper kit test memiliki keunggulan dari segi kepraktisan karena tidak perlu proses pemanasan dalam melakukan uji (Clark, 200I).

Paper kit test formalin yang pernah dibuat adalah paper kit test dengan reagen Schiff (Setianingrum dan Regina, 2018) dan Schryver (Angelina, 2009). Akurasi yang diperoleh pada paper kit tes reagen Schiff sebesar I4I,4326\% dengan persen galat 4I,1656\%. Nilai akurasi tersebut terbilang kurang baik karena akurasi dinyatakan baik apabila nilai perolehan kembali 90-I I0\% dan persen galat mendekati nol. Paper kit test formalin dengan pereaksi Schryver memiliki kekurangan dari segi stabilitas yang buruk (Angelina, 2009).

Alternatif senyawa alam yang bisa digunakan dalam membuat paper kit test adalah dengan ekstrak tanaman. Ekstrak tanaman mengandung berbagai senyawa metabolit sekunder salah satunya adalah antosianin. Antosianin memiliki potensi sebagai indikator formalin karena bersifat sensitif terhadap keberadaan formalin. Antosianin akan mengalami perubahan warna saat ditambahkan dengan formalin.
Potensi antosianin ini dapat dijadikan sebagai reagen alami indentifikasi formalin.

Reagen alami berupa ekstrak tanaman memiliki kelebihan yaitu murah, mudah didapat, serta tidak menimbulkan cemaran seperti reagen sintetis (Nuryanti dkk., 20I0), Terdapat beberapa ekstrak tanaman yang dapat dijadikan sebagai reagen identifikasi formalin ditinjau dari kandungan antosianin yaitu ekstrak kulit buah naga (Dewi, 2019), ekstrak kubis ungu (Sumiati, 2019), dan ekstrak etanol bunga telang (Yuliantini dan Winarsih, 2019). Diantara ketiga ekstrak tersebut, ekstrak bunga telang memiliki kelebihan dari segi kandungan antosianin yang paling tinggi yaitu sebesar 820 ppm (Hartono dkk., 20I2) sedangkan kulit buah naga dan kubis ungu memiliki kandungan antosianin berturut-turut sebesar $280 \mathrm{ppm}$ dan 207, 66 ppm (Ingrath dkk., 2015; Reny dkk., 2019).

Berdasarkan uraian tersebut, dapat dipertimbangkan pengaplikasian ekstrak etanol bunga telang sebagai paper kit test untuk deteksi formalin. Pada penelitian ini akan dilakukan proses pembuatan paper kit test ekstrak etanol bunga telang untuk identifikasi formalin pada makanan. Dengan demikian, diharapkan dapat memberikan gambaran terkait proses pembuatan paper kit test dan dapat dikembangkan lebih lanjut.

\section{Metode}

Alat

Alat-alat yang digunakan adalah botol kaca, botol plastik, pisau, corong, gelas kimia, gunting, kain saring, labu ukur, mortar, oven pengering, penggaris, pipet tetes, pipet volume, pot plastic, sendok tanduk, stamper, tabung reaksi, timbangan analitik, dan wadah maserasi.

\section{Bahan}

Bahan-bahan yang digunakan pada penelitian ini adalah bunga telang segar diperoleh dari Pagutan, etanol p.a (Merck), $\mathrm{HCl}$ pekat p.a (Merck), kertas saring Whattman no.42, larutan baku formalin 40\% p.a (Merck), $\mathrm{NaOH}$ p.a (Merck). plastik mika, dan sampel makanan (ayam, tahu dan ikan) dan

\section{Persiapan Sampel Tanaman}

Sebanyak 50 gram bunga telang segar yang diperolah di daerah Pagutan. Mataram disortasi basah, lalu diperkecil ukuran dengan menggunakan pisau.

\section{Ekstraksi Bunga Telang}

Metode ekstraksi yang dilakukan adalah maserasi dengan perbandingan sampel dengan pelarut yaitu I: 4. Pelarut yang digunakan yaitu etanol p.a $95 \%$ 
diasamkan dengan $\mathrm{HCl} \mathrm{I} \%$ dengan perbandingan 99:I. Proses maserasi dilakukan selama $3 \times 24$ jam. Ekstrak yang diperoleh berupa ekstrak cair tanpa ada proses pengentalan ekstrak.

\section{Skrining Antosianin}

Ekstrak cair $2 \mathrm{ml}$ ditambahkan 2 tetes $\mathrm{NaOH}$ I0\%. Ekstrak selanjutnya ditambahkan 2 tetes $\mathrm{HCl}$ pekat hingga terjadi perubahan warna. Hasil positif ditunjukkan dengan perubahan warna menjadi hijau saat ditambah $\mathrm{NaOH}$ dan merah saat ditambah $\mathrm{HCl}$ (Harborne 1996).

\section{Uji Batas Deteksi Ekstrak}

Ekstrak etanol bunga telang masing-masing sebanyak $2 \mathrm{ml}$ ditambahkan dengan variasi konsentrasi formalin mulai dari $1 \%, 5 \%, 10 \%, 15 \%$, $20 \%, 25 \%, 37 \%$ dan $40 \%$. Hasil positif ditunjukkan dengan perubahan warna ekstrak menjadi biru lebih cerah.

\section{Pembuatan Paper Kit Test}

Paper kit test dibuat dengan memotong kertas Whattman menjadi berukuran $I x 3,5 \mathrm{~cm}$. Kertas tersebut direndam pada ekstrak etanol bunga telang selama 40 menit dan dikeringkan dengan oven pengering bersuhu $50{ }^{\circ} \mathrm{C}$ selama 30 menit. Kertas Whattman tersebut selanjutnya ditempelkan pada kertas mika yang berfungsi sebagai area pegangan.

\section{Penyiapan Sampel Makanan}

Penelitian ini menggunakan 3 jenis sampel makanan yaitu tahu, dada ayam dan ikan tongkol. Tiap-tiap sampel makanan dibagi menjadi 2 kelompok perlakuan yaitu kontrol positif dan kontrol negatif. Pada kontrol positif, sampel makanan direndam dengan formalin I0\% selama 6 jam, sedangkan pada kontrol negatif tidak dilakukan proses perendaman dengan formalin. Sampel makanan pada kedua kontrol dihaluskan dan disaring untuk diperoleh filtrat sampel.

\section{Uji Ekstrak Etanol Bunga Telang Pada Sampel Makanan}

Sebanyak $2 \mathrm{ml}$ fitrat sampel (tahu, dada ayam, dan ikan tongkol) yang telah dibagi menjadi kontrol positif dan kontrol negatif dimasukkan ke tiap-tiap tabung reaksi. Pada tabung reaksi tersebut, ditambahkan beberapa tetes ekstrak etanol bunga telang. Pada kontrol negatif uji dilakukan pada jam ke-0 $(\mathrm{t}=0)$ dan setelah 6 jam penyimpanan dalam lemari pendingin $(t=6)$. Kandungan formalin ditunjukkan dengan perubahan warna menjadi biru lebih cerah. Tiap sampel dilakukan replikasi sebanyak 3 kali.
Uji Paper Kit Test Ekstrak Etanol Bunga Telang Pada Sampel Makanan

Sebanyak $2 \mathrm{ml}$ fitrat sampel (tahu, dada ayam, dan ikan tongkol) yang telah dibagi menjadi kontrol positif dan kontrol negatif dimasukkan ke tiap-tiap tabung reaksi. Pada tabung reaksi tersebut, dimasukkan paper kit test ekstrak etanol bunga telang sampai filtrat sampel mengenai area deteksi paper kit test. Kandungan formalin ditunjukkan dengan perubahan warna menjadi biru lebih cerah. Tiap sampel dilakukan replikasi sebanyak 3 kali. Hasil uji dengan paper kit test dibandingkan dengan test kit formalin pasaran.

\section{Hasil dan Pembahasan}

\section{Ekstraksi Bunga Telang}

Metode maserasi merupakan metode ekstraksi cara dingin yang memiliki mekanisme cairan penyari menembus dinding sel dan masuk ke sitoplasma. Sitoplasma sel mengandung zat aktif sel. Perbedaan konsentrasi antara cairan diluar dan di dalam sel menyebabkan zat aktif keluar dari sel. Zat aktif yang keluar sel akan larut dalam cairan penyari (Sutrisna, 2016). Pemilihan etanol p.a 95\% sebagai pelarut berdasarkan pada sifat "like dissolve like", dimana senyawa marker yang diekstrak yaitu antosianin bersifat polar dan etanol p.a juga bersifat polar. Senyawa yang bersifat polar akan lebih mudah larut dengan menggunakan pelarut polar karena interaksi antar ion-dipol yang kuat (Mittal, 2007). Penambahan $\mathrm{HCl}$ I \% bertujuan untuk meningkatkan kestabilan antosianin, karena antosianin stabil dalam kondisi asam (Anggraeni dkk., 2018). Pemilihan perbandingan 99:I antara etanol 95\% dengan $\mathrm{HCl}$ I\% mengacu pada penelitian oleh Brito dkk., (20I4), dimana pada perbandingan tersebut diperoloeh kadar antosianin tertinggi.

\section{Skrining Antosianin}

Hasil skrining antosianin pada ekstrak etanol bunga telang dapat dilihat pada gambar I.

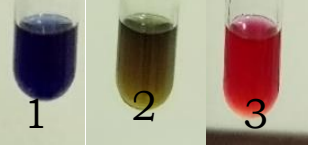

Gambar I. Hasil skrining fitokimia senyawa antosianin Keterangan:

$\mathrm{I}=$ Ekstrak etanol bunga telang sebelum direaksikan

$2=$ Ekstrak etanol bunga telang setelah ditambah $\mathrm{NaOH} 10 \%$

$3=$ Ekstrak etanol bunga telang setelah ditambah $\mathrm{HCl}$ pekat

Berdasarkan gambar I tersebut terlihat bahwa terjadi perubahan warna pada ekstrak setelah ditambah $\mathrm{NaOH}$ dan $\mathrm{HCl}$ pekat. Perubahan warna tersebut menunjukkan hasil positif mengandung antosianin, yaitu menjadi biru kehijauan saat 
ditambah $\mathrm{NaOH}$ dan merah saat ditambah $\mathrm{HCl}$ pekat. Perubahan warna yang terjadi disebabkan oleh sifat antosianin yang sensitif terhadap $\mathrm{pH}$. Antosianin dalam kondisi basa berada pada bentuk qunonoidal base berwarna hijau sedangkan pada kondisi asam dalam bentuk kation flavilum yang berwarna merah (Herfayati dkk., 2020).

\section{Uji Batas Deteksi Ekstrak}

Hasil uji batas deteksi ekstrak etanol bunga telang dapat dilihat pada tabel I.

Tabel I. Hasil Batas Deteksi Ekstrak Etanol Bunga Telang

\begin{tabular}{|c|c|c|}
\hline \multirow{3}{*}{$\begin{array}{l}\text { Konsentrasi } \\
\text { Formalin } \\
\text { I\% }\end{array}$} & \multicolumn{2}{|c|}{ Warna Ekstrak Etanol Bunga Telang } \\
\hline & $\begin{array}{l}\text { Sebelum } \\
\text { ditambah } \\
\text { Formalin }\end{array}$ & $\begin{array}{l}\text { Setelah ditambah } \\
\text { Formalin }\end{array}$ \\
\hline & $\begin{array}{l}\text { Biru } \\
\text { gelap }\end{array}$ & $\begin{array}{l}\text { Biru } \\
\text { gelap }\end{array}$ \\
\hline $5 \%$ & $\begin{array}{l}\text { Biru } \\
\text { gelap }\end{array}$ & $\begin{array}{l}\text { Biru lebih } \\
\text { cerah }\end{array}$ \\
\hline $10 \%$ & $\begin{array}{l}\text { Biru } \\
\text { gelap }\end{array}$ & $\begin{array}{l}\text { Biru lebih } \\
\text { cerah }\end{array}$ \\
\hline $15 \%$ & $\begin{array}{l}\text { Biru } \\
\text { gelap }\end{array}$ & $\begin{array}{l}\text { Biru lebih } \\
\text { cerah }\end{array}$ \\
\hline $20 \%$ & $\begin{array}{l}\text { Biru } \\
\text { gelap }\end{array}$ & $\begin{array}{l}\text { Biru lebih } \\
\text { cerah }\end{array}$ \\
\hline $25 \%$ & $\begin{array}{l}\text { Biru } \\
\text { gelap }\end{array}$ & $\begin{array}{l}\text { Biru lebih } \\
\text { cerah }\end{array}$ \\
\hline $37 \%$ & $\begin{array}{l}\text { Biru } \\
\text { gelap }\end{array}$ & $\begin{array}{l}\text { Biru lebih } \\
\text { cerah }\end{array}$ \\
\hline $40 \%$ & $\begin{array}{l}\text { Biru } \\
\text { gelap }\end{array}$ & $\begin{array}{l}\text { Biru lebih } \\
\text { cerah }\end{array}$ \\
\hline
\end{tabular}

Berdasarkan tabel I terlihat bahwa ekstrak mulai mengalami perubahan warna pada konsentrasi formalin sebesar 5\%. Perubahan warna tersebut menunjukkan ekstrak mulai dapat mendeteksi keberadaan formalin. Perubahan warna yang terjadi yaitu dari biru gelap menjadi biru lebih cerah menunjukkan terjadinya penurunan intensitas warna ekstrak. Penurunan intensitas warna ekstrak dapat disebabkan formalin yang bersifat asam akan berinteraksi dengan antosianin yang bersifat amfoter dalam ekstrak sehingga merubah struktur antosianin menjadi bentuk karbinol sehingga warna biru memudar (Nasution dan Ajeung, 2019; Rahman dan Nursina, 2019).

\section{Uji Ekstrak Etanol Bunga Telang Pada Sampel} Makanan

Hasil uji batas deteksi ekstrak pada makanan dapat dilihat pada gambar 2

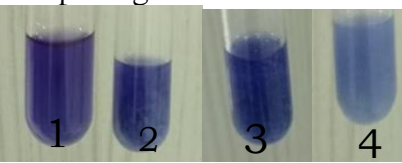

Gambar 2. Perubahan Warna Ekstrak Etanol Bunga Telang

Keterangan:

$\mathrm{I}=$ Ekstrak etanol bunga telang

$2=$ Ekstrak etanol bunga telang yang diuji pada kontrol negatif $\mathrm{t}=0$

$3=$ Ekstrak etanol bunga telang yang diuji pada kontrol negatif $\mathrm{t}=6$

$4=$ Ekstrak etanol bunga telang yang diuji pada kontrol positif

Berdasarkan gambar 2 tersebut terlihat terjadi perubahan warna pada ekstrak saat uji dengan kontrol positif. Formalin yang ditambahkan pada kontrol positif memiliki sifat asam kuat karena mengandung asam format. Sifat asam dari formalin akan memudahkan antosianin dalam mendeteksi keberadaan formalin karena antosianin bersifat sensitif terhadap asam (Priska dkk., 2020).

Pada kontrol negatif, ekstrak etanol bunga telang tidak mengalami perubahan warna yang signifikan atau bisa dikatakan memiliki warna yang serupa dengan ekstrak etanol bunga telang sebelum diuji. Pengujian pada kontrol negatif dilakukan sebanyak 2 kali yaitu pada saat waktu $\mathrm{ke}=0$ jam $(\mathrm{t}=0)$ dan setelah disimpan di lemari pendingin selama 6 jam $(\mathrm{t}=6)$ untuk melihat apakah ada perbedaan hasil uji antara sampel makanan yang masih segar maupun yang telah disimpan selama 6 jam di lemari pendingin. Berdasarkan hasil pengujian, terihat bahwa tidak ada perbedaan hasil uji antara kontrol negatif pada waktu ke-0 dan setelah disimpan selama 6 jam.

Berdasarkan perubahan warna tersebut dapat disimpulkan bahwa ekstrak etanol bunga telang dapat mendeteksi kandungan formalin pada sampel makanan (tahu, dada ayam dan ikan tongkol) yang ditandai dengan perubahan warna ekstrak dari warna biru tua ke biru muda. Perubahan warna ini disebabkan karena perubahan struktur antosianin dari bentuk quinonoidal menjadi bentuk karbinol $(\mathrm{pH}=5)$ (Rahman dan Nursina, 2019). Perubahan struktur menjadi bentuk quinonoidal menyebabkan terjadinya penurunan intensitas warna biru dari ekstrak. Perubahan struktur antosianin berdasarkan nilai $\mathrm{pH}$ dapat dilihat pada gambar 3 


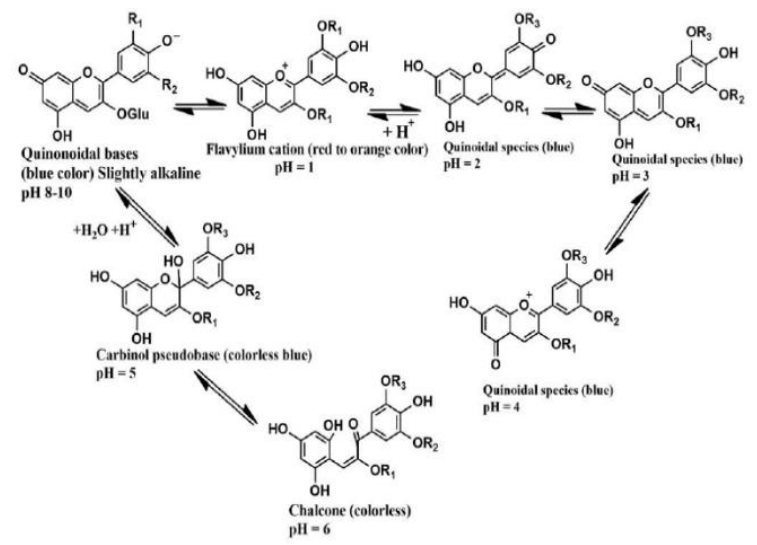

Gambar 3. Perubahan Struktur dan Warna Antosianin Berdasarkan Nilai pH (Evangeline dkk., 2020)

\section{Uji Paper Kit Test Ekstrak Etanol Bunga Telang Pada Sampel Makanan}

Hasil pengujian paper kit test ekstrak etanol bunga telang pada sampel makanan dapat dilihat pada gambar 4 .

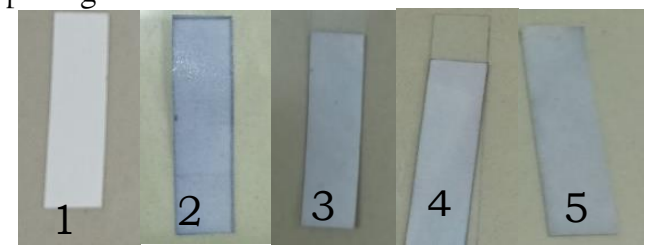

Gambar 4. Perubahan Warna Paper Kit Test Ekstrak Etanol Bunga Telang

Keterangan:

$\mathrm{I}=$ Kertas Whattman sebelum direndam ekstrak etanol bunga telang $2=$ KertasWhattman setelah direndam ekstrak etanol bunga telang

$3=$ Paper Kit Test Ekstrak Etanol Bunga Telang yang sudah jadi

$4=$ Paper Kit Test Ekstrak Etanol Bunga Telang yang diuji pada kontrol negatif

5= Paper Kit TestEkstrak Etanol Bunga Telang yang diuji pada kontrol positif

Pada gambar tersebut dapat dilihat tidak terjadi perubahan warna yang signifikan pada paper kit test Perubahan warna yang tidak signifikan menyebabkan paper kit test tidak dapat mendeteksi keberadaan formalin pada sampel makanan karena tidak dapat dibedakan antara kontrol positif maupun negatif. Tidak terdeteksinya formalin pada sampel makanan dengan paper kit test ekstrak etanol bunga telang dapat disebabkan oleh pemilihan media dalam pembuatan paper kit test serta stabilitas antosianin.

Media dalam pembuatan paper kit test memiliki peran sebagai area pendeteksian analit. Media yang digunakan harus dapat mengabsorbsi reagen yang digunakan, sehingga reaksi spesifik antara reagen dalam paper kit test dengan analit dapat berlangsung. Pemilihan kertas Whattman sebagai media karena kertas tersebut memiliki kemampuan absorbsi yang baik, mudah dipeorleh dan harga yang terjangkau (Nurhasnawati dkk., 2020). Namun, pada penelitian ini penggunaan kertas Whattman sebagai media ternyata tidak memberikan hasil yang maksimal, karena absorbsi antosianin yang kurang baik. Indikator suatu reagen terabsorbsi dengan baik adalah terjadi perubahan warna pada media (kertas) menjadi warna yang menyerupai reagen. Pada kertas Whattman warna yang dihasilkan adalah ungu sedangkan warna reagen yang digunakan adalah biru gelap. Proses pendeteksian reagen dengan analit (Formalin) tidak memberikan perubahan warna yang signifikan menyebabkan data yang diperoleh tidak dapat diinterpretasikan karena uji ini hanya sebatas pengamatan visual melalui perubahan warna. Alternatif lain yang dapat digunakan untuk mengganti kertas Whattman yaitu selolusa. Menurut penelitian oleh Wastito dkk (2017), media selulosa memberikan hasil yang baik dari segi absorbsi karena menghasilkan perubahan warna yang baik pada paper kit test. Kertas selulosa juga memiliki nilai sensitivitas yang baik. Perbedaan kertas saring Whattman dan selulosa terletak pada komposisi dari kertas tersebut. Kertas saring Whattman mengandung 98\% selulosa, sedangkan kertas selulosa mengandung I00\% selulosa (Getrebsadik, 200I). Selulosa berperan dalam proses absorpsi karena pada permukaannya terdapat gugus hidroksil yang membentuk ikatan hidrogen dengan (reagen) yang secara langsung mempengaruhi penyerapan dengan reagen (Vieira dkk., 2020)

Stabilitas antosianin memiliki perngaruh yang sangat penting karena antosianin yang berperan sebagai reagen pada paper kit test. Antosianin yang tidak stabil menyebabkan kemampuannya untuk melakukan reaksi dengan formalin menjadi berkurang sehingga perubahan warna yang dihasilkan tidak signifikan. Kestabilan antosianin dapat dipengaruhi oleh beberapa faktor yaitu: $\mathrm{pH}$, suhu, waktu penyimpanan, cahaya, oksigen, enzim, protein serta ion logam (Rein, 2005). Pada penelitian ini, kestabilan antosianin dipengaruhi oleh suhu. Pada proses pembuatan paper kit test, terdapat proses pengeringan dengan oven pada suhu $50{ }^{\circ} \mathrm{C}$. Antosianin yang terkandung pada ekstrak dapat mengalami degradasi oleh enzim polifenol oksidase. Enzim ini akan aktif pada suhu menengah berkisar $50{ }^{\circ} \mathrm{C}$ (Patras dkk., 2010). Penelitian yang dilakukan oleh Oancea dan Olga (2013) menunjukkan peningkatan suhu dari $45-50 \quad{ }^{\circ} \mathrm{C}$ menyebabkan dekomposisi pada antosianin. Pada penelitian ini, proses ekstraksi sudah ditambahkan pelarut asam yaitu $\mathrm{HCl} \mathrm{I} \%$ untuk meningkatkan kestabilan antosianin, tetapi antosianin tetap mengalami degradasi karena pemanasan. Pelarut asam yang ditambahkan tergolong sedikit karena perbandingan I:99 dengan etanol. Kondisi ini menyebabkan 
antosianin tidak berada dalam kondisi kation flavillium yang ditandai dengan warna ekstrak berwarna merah. Menurut penelitian yang dilakukan oleh Oancea dan Olga (2013) dan Wahyuningsih (2017) antosianin dalam bentuk kation flavillum memiliki kestabilan yang tinggi sehingga sulit terdegradasi.

Pada uji formalin dengan test kit formalin pasaran diperoleh hasil yaitu mampu mendeteksi ketiga sampel dengan tepat baik kontrol positif maupun kontrol negatif. Pada kontrol positif sampel makanan akan berubah menjadi berwarna ungu muda sampai ungu tua, sedangkan pada kontrol negatif sampel makanan tetap berwarna putih atau sesuai dengan warna asli filtrat sampel.

\section{Simpulan dan Saran}

Pada penelitian ini paper kit test ekstrak etanol bunga telang belum berhasil dibuat karena tidak terabsorbsinya antosianin pada kertas Whattman

Berdasarkan penelitian yang dilakukan, perlu dilakukan studi lanjutan seperti membuat paper kit test dengan menggunakan kertas selulosa yang memiliki absorbsi lebih baik dari Whattman atau dengan mengganti ekstrak lain yang lebih bisa diabsorbsi Whattman.

\section{Daftar Pustaka}

Angelina, P. (2009), Optimasi pereaksi schryver menggunakan media kertas dan tisu basah untuk identifikasi formalin dalam sampel makanan, Skripsi, Universitas Indonesia.

Anggraeni, V.J., Ramdanawati, L., dan Winda, A. (2018). Penetapan Kadar Antosianin Total Beras Merah (Oryza nivara). Jurnal Kartika Kimia; I(I), I I-I6.

Badan Pengawas Obat dan Makanan. (2018). Laporan Tahunan BPPOM NTB Tahun 2018. Mataram: Badan Pengawas Obat dan Makanan RI.

Badan Pengawas Obat dan Makanan. (2017). Laporan Tahunan BPOM 2017. Jakarta: Badan Pengawas Obat dan Makanan RI.

Brito, B.N.C., Pena, R.S., Lopes, A.S., dan Renan, C.C. (20I4). Anthocyanins of Jambolao (Syzygium cumini): Extraction and $\mathrm{pH}-$ Dependent Color Change. Journal of Food Science; 82(I0), 2286-2290.

Clark, S., Thompson, K., Keevil, W dan Mark, S. (200I). Rapid Detection Assay For Food and Water. Cambridge: The Royal Society of Chemistry.

Daoudy, B. D. A. D., Al-Khayat, M.A., Karabet, F., dan Mohammad, A.A. (2018). A robust static headspace GC-FID method to detect and quantify formaldehyde impurity in pharmaceutical excipients. Journal of Analytical Methods in Chemistry; I3-I7.

Dachriyanus. (20I4). Analisis Struktur Senyawa Organik Secara Spektroskopi. Padang: LPTIK Universitas Andalas.

Dewi, S.R. (2019). Identifikasi formalin pada makaan menggunakan ekstrak kulit buah naga. Jurnal Nasional Ilmu Kesehatan; 2(I), 46-5I.

Evangeline, I., Barithazar, N., dan Gakuba, E. (2020). Biosynthesis of Anthocyanins and Their Apllication as Food Additives. Journal of Academia and Indsutrial Research; 9(I), I0-20.

Gebretsadik, S. (200I), Interaction of Water With Filter Paper Cellulose/Fiber Structure in Soil Suction Measurements, Thesis. Universitas Addis Ababa. Ethiopia.

Harborne, J.B. (I966). Metode Fitokimia : Penuntun Cara Modern Menganalisis Tumbuhan (Terjemahan: Kosasih Padmawinata dan Iwang Soediro). Bandung: ITB

Hartono, M.A., Purwijantiningsih, E., dan Sinung, P. (2012). Pemanfaatan Ekstrak Bunga Telang (Clitoria ternatea L.) sebagai pewarna alami es lilin. Fakultas Teknobiologi Universitas Atma Jaya; II4.

Herfayati, P., Pandia, S., Nasution., dan Halimatuddahliana, N. (2020). Karakteristik Antosianin dari Kulit Buah Nipah (Nypa frutican) Sebagai Pewarna Alami dengan Metode Soxhletasi. Jurnal Teknik Kimia USU; 9(I), 26-33.

IARC. (2006). IARC monographs on the evaluation of carcinogenic risks to humans: Formaldehyde, 2-Butoxyethanol and I-tertButoxypropan-2-ol Vol. 88. IARC.

Ingrath, W., Nnugroho, W.A., dan Rini, Y. (2015). Ekstraksi pigmen antosianin dari kulit buah naga merah (Hylocereus costaricensis) sebagai pewarna alami makanan dengan menggunakan microwave (kajian waktu pemanasan dengan microwave dan penambahan rasio pelarut aquades dan asam sitrat). Jurnal Bioproses Komoditas Tropis; 3(3), 3-8.

Mamun, M.A.A., Rahman, M.A., Zaman, M.K., Ferdousi, Z., dan Abu, R. (20I4). Toxicological effect of formalin as food preservative on kidney and liver tissue in mice model. IOSR Journal of Enviromental 
Science, Toxicology and Food Technology; $8(9) .47-51$

Mittal, A. (2007). Chemistry. New Delhi: APH Publishing Coorporation.

Nasution, A.S., dan Ajeung, E.S.S. (2019). Pemanfaatan Ekstrak Antosianin Dari Kulit Buah Naga Untuk Iidentifikasi Formalin Pada Tahu Dengan Simple Methods. Jurnal Gizi KH; I(2), 82-86.

Nurhasnawati,H., Sentat, T dan Adi, P. (2020). Pembuatan Strip Test dan Identifikasi Fenilbutazon Pada Jamu Pegal Linu. Jurnal Ilmiah Manuntung; 6(2). 280-285

Nuryanti, S., Matsjeh, S., Anwar, C., dan Tri, J.R. (2010). Indikator Titrasi Asam-Basa dari Ekstrak Bunga Sepatu (Hibiscus rosa sinensis L). AGRITECH; .30(3), I78I83

Oancea, S., dan Olga, D. (2013). pH and Termal Stability of Anthocyanin-based Optimised Extracts of Romanian Red Onion Cutivar. Czech J. Food Sci; 3I(3), P. 283-29I

Patras, A., Brunton, N.P., O'Donnell, C., dan Tiwari, B.K. (2010). Effect of Thermal Processing on Anthocyanin Stability in Foods; Mechanism and Kinetic of Degradation.Trends in Food Science and Technology; 2I, 3-II.

Priska, M., Peni, N., Carvallo, L., dan Ngapa, Y.D. (2018). Review: Antosianin dan Pemanfaatannya. Cakra Kimia; 63 (2), 7997.

Rahman, N., dan Nursina, S. (2019). Pengembangan Buku Petunjuk Praktikum Uji Formalin Dan Boraks Untuk Siswa Smp. Jurnal Ulul Albab; 23 (I), I-7.

Rein, M. (2005), Copigmentation reaction and color stability of berry anthocyanin, Disertasi, Universitas of Helsinki.

Reny, S., Ana, N., Rika, S., dan A'yun, Q. (2019). Pemanfaatan ekstrak kubis ungu (Brassica Ooleraceae) sebagai indikator warna pada analisis hidrokuinon. Akta Kimia Indonesia; 4(2), 95-I06.

Rohmatun, Y. (2010). Ensiklopedia Sistem Koloid dan Hidrokarbon. Semarang: Alprin

Setianingrum, R., dan Regina, T.P. (2016). Validasi paper test untuk uji formalin dengan pereaksi Schiff. Jurnal FMIPA UNY.

Siswandono. (2016). Kimia Medisinal II Edisi II. Surabaya: Airlangga University Press

Sumiati. (2019). Purple cabbage extracts (Brasicca oleracea $L$ ) as tofu's formalin indicators. Intergrated Lab Journal;7(I), 44-55.

Sutrisna, E.M. (2016). Herbal Medicine: Suatu Tinjauan Farmakologis. Surakarta: Muhammadiyah University Press.

Trevethan, R. (2017). Sensitivity, specificity, and predictive values: Foundations, pliabilities, and pitfalls in research and practice. Frontiers in Public Health; 5, I-7.

Vieira, J.C., Mendes, A.D., Carta, A.M., Galli, E., Fiadeiro, P.T., dan Ana, P.C. (2020). Peer reviewed article Impact of Embosing on Liquid Absorption of Toilet Tissue Papers.BioResources; I5(2), p. 38883898

Wahyuningsih, S., Wulandari, L., Wartono, M.W., Munawaroh, H., dan Ramelan. (2016). The Effect of Ph and Color Stability of Anthocyanin on Food Colorant. International Conference On Food Science and Engineering; I93, p, I-IO

Wasito, H., Karyati, E., Vikarosa, C.D., Hafizah, I.N., Utami, H.R., dan Medi, K. (2017). Test Strip Pengukur pH dari Bahan Alam yang Diimmobilisasi dalam Kertas Selulosa. Indonesian Journal of Chemical Science; 6(3), 223-229.

Yuliantini, A dan Winarsih, R. (2019). Deteksi formalin dalam makanan dengan indikator alami dari ekstrak bunga telang (Clitoria Ternatea L.). Journal of Pharmacopolium; I(3), I07-II3. 